\title{
PENINGKATAN KUALITAS PEMBELAJARAN IPS MELALUI PEMANFAATAN MODEL KELAS DI KELAS V SEKOLAH DASAR NEGERI 38 KOTA BENGKULU
}

\author{
Sri Dadi \\ Universitas Bengkulu
}

\begin{abstract}
Abstrak
Penelitian ini bertujuan untuk : (1) Meningkatkan kemampuan guru dalam membuat rencana pembelajaran, (2) Meningkatkan kualitas proses pembelajaran IPS, dan (3) Meningkatkan kualitas hasil belajar siswa pada pembelajaran IPS melalui pemanfaatan model kelas di kelas V SD N 38 Kota Bengkulu. Metode yang digunakan yaitu Penelitian Tindakan Kelas (PTK). Tahapan PTK adalah perencanaan, pelaksanaan, observasi dan refleksi. Hasil penelitian menunjukkan bahwa pemanfaatan model kelas dapat meningkatkan : (1) kemampuan guru dalam membuat rencana pembelajaran, (2) kualitas proses pembelajaran IPS, dan (3) hasil belajar siswa pada pembelajaran IPS di kelas V SD N 38 Kota Bengkulu. Saran yang di sampaikan yakni : (1) Guru diharapkan dapat memanfaatkan model kelas dalam pembelajaran selain IPS, dan (2) Kepada sekolah diharapkan mendorong guru untuk memanfaatkan model kelas.
\end{abstract}

Kata Kunci : Kualitas Pembelajaran, IPS, Model Kelas.

\section{PENDAHULUAN}

Penyelenggaraan pendidikan pada jenjang sekolah dasar bertujuan memberikan bekal kepada siswa untuk hidup bermasyarakat dan dapat melanjutkan pendidikan ke jenjang yang lebih tinggi. Pada kurikulum sekolah dasar, pendidikan IPS merupakan salah satu mata pelajaran yang wajib diajarkan secara formal mulai kelas IV sampai kelas VI. Pembelajaran pendidikan IPS pada jenjang sekolah dasar dewasa ini dihadapkan pada tantangan untuk mempersiapkan manusia Indonesia yang mampu memerankan diri dalam kehidupan dunia modern.

Melalui pendidikan IPS diharapkan lahir manusia-manusia Indonesia yang mempunyai jiwa dan semangat yang tangguh dalam mendukung dan melaksanakan pembengunan nasional sesuai dengan tujuan pendidikan nasional. Hal ini sesuai dengan tujuan pendidikan IPS di tingkat sekolah dasar, yaitu untuk mengembangkan pengetahuan dan keterampilan dasar yang berguna bagi peserta didik dalam kehidupan sehari-hari dan sebagai bekal melanjutkan pendidikan ke jenjang yang lebih tinggi (Depdiknas.2004). Di samping itu melalui pendidikan IPS diharapkan mampu dikembangkan sikap, nilai moral, dan seperangkat keterampilan hidup bermasyarakat dalam rangka mempersiapkan warga negara yang baik dan mampu bermasyarakat.

Memperhatikan tujuan dan esensi pendidikan IPS di sekolah dasar seyogyanya penyelenggaraan pembelajaran pendidikan IPS mampu mempersiapkan, membina dan membentuk kemampuan peserta didik yang menguasai pengetahuan, sikap, nilai dan kecakapan dasar yang diperlukan bagi kehidupannya di masyarakat (Hasan, 1996). Untuk menunjang keberhasilan tujuan 
pendidikan IPS seperti itu diperlukan guru yang baik.

Guru yang baik mempunyai tiga kemampuan yang bersifat "generic essensial". Yaitu: kemampuan membuat rencana pengajaran, kemampuan melakukan prosedur pengajaran dan kemampuan melakukan hubungan antar pribadi (Mulyasa, 2007). Dari ketiga aspek tersebut, ada dua aspek yang sangat penting yaitu kemampuan membuat rencana pengajaran dan kemampuan melakukan prosedur pengajaran, karena kedua aspek tersebut sangat berkaitan dengan guru dalam melakukan prosedur pembelajaran tentu berdasarkan pada perencanaan yang telah dibuat (rencana pembelajaran). Apabila perencanaan pembelajaran dibuat dengan baik dan tepat, tentu dalam pelaksanaan pembelajaran diharapkan juga baik.

Berdasarkan hasil pengamatan peneliti, khususnya mata pelajaran IPS di Sekolah Dasar Negeri 38 Kota Bengkulu terjadi "kesenjangan dalam proses mengajar" di antaranya: kemampuan profesional yang ditampilkan dan dimiliki guru pas-pasan, guru kurang memperhatikan kebutuhan siswa. Hal ini nampak pada rencana pembelajaran (RP) yang dibuat oleh guru belum dapat dikategorikan baik, bila dilihat dari perumusan TPK, pemilihan metode pembelajaran, kegiatan belajar mengajar, pemilihan media dan sumber belajar. Di samping itu pada saat guru melakukan proses pembelajaran, ia hanya menggunakan sumber belajar berupa buku penunjang atau buku paket. Padahal di lingkungan sekitar sekolah banyak sumber belajar yang dapat dimanfaatkan untuk mendukung proses pembelajaran. Berkaitan dengan permasalahan tersebut di atas tentu akan bermuara pada hasil belajar yang diperoleh siswa. Berdasarkan informasi dari guru kelas $\mathrm{V}$ nilai rata- rata pembelajaran IPS adalah
62. Nilai tersebut masih di bawah kategori baik. Untuk itu perlu dicari alternatif pemecahan masalah yang terjadi di sekolah dasar tersebut.

Sehubungan dengan permasalahan di atas, maka upaya peningkatan kualitas pembelajaran IPS merupakan suatu kebutuhan yang sangat mendesak untuk dilakukan. Salah satu alternatif yang diduga dapat menjembatani keresahan tersebut adalah dengan memanfaatkan model kelas dalam pembelajaran IPS di kelas V SDN 38 Kota Bengkulu.

Pembelajaran IPS dengan memanfaatkan model kelas merupakan salah satu alternatif bentuk pembelajaran yang dipilih untuk memperbaiki proses pembelajaran IPS di SDN 38 Kota Bengkulu. Sebelum pelaksanaan pembelajaran IPS di model kelas, guru membuat media/alat peraga yang akan digunakan pada saat pembelajaran IPS di model kelas. Pelaksanaan pembelajaran di model kelas akan memberikan pengalaman langsung pada aktivitas belajar siswa SD. Salah satu pengelolaan model kelas yang baik adalah menyediakan kesempatan kepada siswa dan mendorongnya untuk belajar mandiri (inkuiri) secara bertahap, sehingga sedikit demi sedikit mengurangi ketergantungan kepada guru yang pada akhirnya memiliki kemampuan dalam membimbing kegiatannya sendiri (Zulkarnain, 2004).

Model kelas merupakan sumber belajar tidak terbatas pada pemeliharaan dan penciptaan suasana belajar yang efektif, malainkan juga dapat sebagai tempat pameran hasil karya siswa (Udin, 2002). Kelas yang memiliki pajangan atau pameran hasil karya siswa dapat menjadi tempat yang menarik dan dapat memotivasi siswa untuk belajar. Suatu kelas yang kosong tanpa pajangan dapat menjadi tempat yang membosankan, gersang dan tidak 
menggugah inspirasi siswa. Kelas yang baik memiliki banyak pajangan, terutama pajangan hasil karya siswa dan hanya meliputi apa yang sedang dipelajari siswa. Pajangan yang kurang relevan dengan apa yang sedang dipelajari siswa akan kurang bernilai dan hanya merupakan hiasan dinding belaka.

Berdasarkan kajian permasalahan yang diuraikan di atas, penelitian ini memanfaatkan model kelas pada pembelajaran IPS sebagai suatu proses yang berlangsung secara terencana dan terarah dalam dimensi pembelajaran. Untuk itu penelitian ini diarahkan pada peningkatan kualitas pembelajaran IPS melalui pemanfaatan model kelas di kelas V SDN 38 Kota Bengkulu. Model kelas yang dimaksud dalam penelitian ini adalah model kelas yang terdapat di PGSD FKIP Universitas Bengkulu.

$$
\text { Tujuan penelitian adalah }
$$

Meningkatkan kemampuan guru dalam membuat rencana pembelajaran (RP) melalui pemanfaatan model kelas pada pembelajaran IPS di kelas V SD N 38 Kota Bengkulu, (2) Meningkatkan kualitas proses pembelajaran IPS melalui pemanfaatan model kelas di kelas V SD N 38 Kota Bengkulu, dan (3) Meningkatkan kualitas hasil belajar siswa pada pembelajaran IPS dengan memanfaatkan model kelas di kelas V SD N 38 Kota Bengkulu.

\section{METODE}

Penelitian ini menggunakan metode penelitian tindakan (action research). Pemilihan metode penelitian tersebut berdasarkan pada tujuan dan karakteristik masalah penelitian. Langkah pertama kegiatan penelitian model ini, diawali dengan melakukan penelitian pendahuluan. Observasi dilakukan terhadap SD N 38 Kota
Bengkulu. Hasil temuan dari sekolah tersebut dilakukan refleksi antara dosen peneliti dengan guru SD untuk menentukan langkah-langkah kegiatan selanjutnya hingga tujuan penelitian tercapai. Pola kegiatan penelitian seperti ini dikategorikan dalam bentuk educational action research (Hopkins, 1993).

\section{HASIL}

\section{Tahap Pelaksanaan Penelitian Tindakan Pertama}

Temuan penelitian pada tindakan pertama dari kegiatan penelitian dapat dikemukakan sebagai berikut :

1. Kemampuan guru dalam membuat "Rencana Pembelajaran"

Kemampuan guru dalam membuat rencana pembelajaran dapat dikategorikan baik. Hal ini dapat dibuktikan dengan nilai rata-rata komponen rencana pembelajaran sebesar 4,44.

2. Kualitas proses pembelajaran IPS

Kualitas proses pembelajaran IPS yang dilakukan oleh guru dapat dikategorikan baik. Hal ini dapat dibuktikan pada kondisi pembelajaran IPS yang dilakukan guru di kelas $\mathrm{V}$ nilai rataratanya sebesar 4,33 .

3. Kualitas hasil belajar siswa pada pembelajaran IPS

Kualitas hasil belajar siswa pada pembelajaran IPS di kelas V SD N 38 Kota Bengkulu untuk nilai klompok dapat dikategorikan cukup, karena nilai rata-rata kelompok sebesar 64,6. Sedangkan nilai rata-rata individual sebesar 64,32 dan ketuntasan belajarnya adalah $47,5 \%$ 
Tahap Pelaksanaan Penelitian Tindakan Kedua

Temuan penelitian pada tindakan kedua dari kegiatan penelitian dapat dikemukakan sebagai berikut :

1. Kemampuan guru dalam membuat "Rencana Pembelajaran"

Kemampuan guru dalam membuat rencana pembelajaran dapat dikategorikan sangat baik. Hal ini dapat dibuktikan dengan nilai rata-rata komponen rencana pembelajaran sebesar 4,58.

2. Kualitas proses pembelajaran IPS

Kualitas proses pembelajaran IPS yang dilakukan oleh guru dapat dikategorikan sangat baik. Hal ini dapat dibuktikan pada kondisi pembelajaran IPS yang dilakukan guru di kelas $\mathrm{V}$ nilai rataratanya sebesar 4,63.

3. Kualitas hasil belajar siswa pada pembelajaran IPS

Kualitas hasil belajar siswa pada pembelajaran IPS di kelas V SD N 38 Kota Bengkulu untuk nilai klompok dapat dikategorikan baik, karena nilai rata-rata kelompok sebesar 90. Sedangkan nilai rata-rata individual sebesar 70,26 dan ketuntasan belajarnya adalah $75,73 \%$

\section{PEMBAHASAN}

Hipotesis umum berbunyi “Apabila memanfaatkan model kelas pada pembelajaran IPS maka kualitas proses pembelajaran dapat meningkat di kelas V SD N 38 Kota Bengkulu". Hipotesis ini teruji kebenarannya, sebab baik mutu rencana, proses, dan hasil belajar siswa pada pembelajaran IPS seluruhnya dapat ditingkatkan dengan memanfaatkan model kelas. Pengujian hipotesis ini terlihat dari terujinya hipotesis khusus di bawah ini.
Pertama, berdasarkan hasil penelitian menunjukan bahwa kemampuan guru dalam membuat rencana pembelajaran IPS dengan memanfaatkan model kelas secara signifikan meningkat. Hal ini terbukti dari pelaksanaan tindakan dengan indikator keberhasilan PTK $(3,60)$; skor pada tindakan pertama sebesar 4,44 (baik); dan skor pada tindakan kedua 4,58 (sangat baik). Penerapan PTK dengan dua kali tindakan ini skor perolehannya meningkat. Peningkatan skor pada tindakan pertama dan kedua sebesar 0,14. Berdasarkan dua kali tindakan pembelajaran IPS dengan memanfaatkan model kelas mampu membuktikan peningkatan skor. Hal ini berarti melalui pemanfaatan model kelas mampu meningkatkan kemampuan guru dalam membuat rencana pembelajaran IPS di kelas V SD N 38 Kota Bengkulu.

Kedua, berdasarkan hasil penelitian menunjukkan bahwa kualitas proses pembelajaran IPS melalui pemanfaatan model kelas secara signifikan meningkat. Hal ini terbukti dari pelaksanaan tindakan dengan indikator keberhasilan PTK $(3,60)$; skor pada saat tindakan pertama sebesar 4,33 (baik); dan skor pada tindakan kedua sebesar 4,63 (sangat baik). Penerapan PTK dengan dua kali tindakan ini skor perolehannya meningkat. Peningkatan skor pada tindakan pertama dan kedua sebesar 0,30. Berdasarkan dua kali tindakan pembelajaran IPS melalui pemanfaatan model kelas mampu memberikan peningkatan skor. Hal ini berarti melalui pemanfataan model kelas mampu meninkatkan kualitas proses pembelajaran IPS di kelas V SD N 38 Kota Bnegkulu.

Dalam pembelajaran guru hendaknya membimbing siswa dengan memberikan pertanyaan-pertanyaan untuk mempermudah siswa menemukan sendiri konsep-konsep yang dipelajari. Hal ini senada dengan pendapat Hamalik (2007) bahwa 
pembelajaran yang efektif adalah pembelajaran yang mampu mengoptimalkan kemampuan siswa untuk mengkontruksi pengetahuan. Pembelajaran IPS melalui pemanfaatan model kelas memberikan pengetahuan langsung kepada siswa untuk belajar membangun pengetahuannya sendiri.

Ketiga, berdasarkan hasil penelitian menunjukkan bahwa hasil belajar siswa pada pembelajaran IPS dapat ditingkatkan melalui pemanfaatan model kelas di kelas V SD N 38 Kota Bengkulu. Hal ini terbukti dari pelaksanaan tindakan dengan indikator keberhasilan 70,0 (baik); skor rata-rata kelompok pada saat tindakan pertama sebesar 64,6; dan pada tindakan kedua sebesar 90. Sedangkan skor rata-rata individual pada tindakan pertama sebesar 64,32 dan ketuntasan belajarnya 47,5\%; dan pada tindakan kedua sebesar 70,26 dan ketuntasan belajarnya 75,73\%. Berdasarkan dua kali tindakan pembelajaran IPS melalui pemanfaatan model kelas mampu memberikan peningkatan skor. Hal ini berarti melalui pemanfaatan model kelas mampu meningkatkan hasil belajar siswa pada pembelajaran IPS di kelas V SD N 38 Kota Bengkulu.

Hasil belajar adalah proses pemberian nilai terhadap hasil-hasil belajar yang dicapai siswa dengan kriteria tertentu (Sudjana. 2004). Hasil belajar yang dicapai menunjukkan seberapa jauh siswa menguasai materi pelajaran yang telah dipelajari. Hal ini sesuai dengan tujuan dari penilaian hasil belajar yang dikemukakan oleh Sudjana (2004) yaitu : (1) mendeskripsikan kecakapan belajar pada siswa sehingga dapat diketahui kelebihan dan kekurangan dalam berbagai bidang studi atau mata pelajaran yang ditempuh, (2) mengetahui keberhasilan proses pendidikan dan pengajaran di sekolah, yakni seberapa jauh keefektifannya dalam mengubah tingkah laku pada siswa ke arah tujuan pendidikan yang diharapkan, (3) menentukan hasil tindaklanjut dari hasil penelitian, yakni melakukan perbaikan dan penyempurnaan dalam hal program pendidikan dan pengajaran serta strategi pelaksanaannya, dan (4) memberikan pertanggungjawaban dari pihak sekolah kepada pihak-pihak yang berkepentingan. Pembelajaran IPS melalui pemanfaatan model kelas terbukti dapat meningkatkan hasil belajar siswa di kelas V SD N 38 Kota Bengkulu.

\section{SIMPULAN}

Berdasarkan temuan hasil penelitian yang telah dikemukakan, maka dapat diambil kesimpulan sebagai berikut :

1. Pemanfaatan model kelas dapat meningkatkan kemampuan guru dalam membuat rencana pembelajaran IPS di kelas V SD N 38 Kota Bengkulu.

2. Pemanfaatan model kelas dapat meningkatkan kualitas proses pembelajaran IPS di kelas V SD N 38 Kota Bengkulu

3. Pemanfaatan model kelas dapat meningkatkan hasil belajar siswa pada pembelajaran IPS di kelas V SD N 38 Kota Bengkulu.

\section{SARAN}

Saran yang dapat diajukan terkait dengan hasil penelitian ini sebagai berikut :

1. Guru diharapkan dapat memanfaatkan model kelas dalam pembelajaran selain IPS

2. Kepala sekolah diharapkan mendorong guru untuk memanfaatkan model kelas 
Sri Dadi

\section{DAFTAR PUSTAKA}

Depdiknas. 2004. Kurikulum 2004. Standar

Kompetensi Sekolah Dasar dan MI. Jakarta.

Hasan, Hamid. 1996. Pendidikan Ilmu-Ilmu Sosial. Bandung. Jurusan Pendidikan Sejarah FP IPS IKIP Bandung.

Hopkins. 1993. A Teacher Guide to Classroom Research Philadelphia. Open University Press.

Hamalik, Oemar. 2007. Pendidikan Guru. Jakarta. Bumi Aksara.

Mulyasa. 2007. Menjadi Guru Profesional. Bandung. Rosda.

Zulkarnain , Rufran. 2004. Model Kelas SD. PGSD FKIP. Universitas Bengkulu.

Sudjana. 2004. Penilaian Hasil Belajar Mengajar. Bandung. PT Remaja Rosdakarya.

Udin, S. Winataputra. 2002. Materi dan Pembelajaran IPS SD. Jakarta. Universitas Terbuka. 